\title{
DOMINAÇÃO CARISMÁTICA EM MAX WEBER: BOLSONARO NA ÓTICA WEBERIANA
}

\author{
CHARISMATIC DOMINATION IN MAX WEBER: \\ BOLSONARO UNDER WEBERIAN PERSPECTIVE
}

\author{
Solange Maria da Conceição dos Santos ${ }^{1}$ \\ Francisco Roberto Pinto ${ }^{2}$ \\ Ebe Pimentel Gomes Luz Nijdam ${ }^{3}$
}

\section{RESUMO}

Este trabalho analisa os conceitos desenvolvidos por Max Weber sobre política e dominação, dialogando com eleição de 2018 para presidência da República. Trata-se de uma pesquisa exploratório-descritivo de natureza qualitativa, com abordagem teórica pautada nas ideias de Max Weber, fundamentada em dados secundários e publicações em jornais. Ao final conclui-se que o comportamento de Bolsonaro como presidente não se enquadra no cargo que ele exerce, passou de mito a "governante incipiente, insensível às causas sociais, à saúde e às mortes ocorridas no Brasil em consequência da COVID-19.

Palavras-chaves: Max Weber; Dominação Carismática; Eleições 2018.

\begin{abstract}
This paper analyzes Max Weber's concepts on politics and domination and its connections with the 2018 election for Brazil's presidency. It is based on qualitative exploratory-descriptive research that uses Max Weber's ideas as a theoretical approach and works with secondary data and newspapers publications. In the end, we infer that Bolsonaro's behavior as president does not fit his position; he went from "myth" to "incipient ruler," insensitive to social causes, health, and deaths that occurred in Brazil due to COVID-19.
\end{abstract}

Keywords: Max Weber; Charismatic Domination, Elections 2018.

\footnotetext{
${ }^{1}$ Atualmente é Doutoranda em Políticas Públicas pela Universidade Estadual do Ceará. Mestre em Planejamento e Políticas Públicas - UECE. e-mail: solangemcsantosadv@gmail.com

2 Atualmente é Professor dos cursos de Graduação, Mestrado e Doutorado em Administração da Universidade Estadual do Ceará (UECE). Pós-doutor em Administração pelo PROPAD da Universidade Federal de Pernambuco. Doutor em Gestão de Empresas pela Universidade de Coimbra (2008). e-mail: roberto.pinto@uece.br
}

\footnotetext{
${ }^{3}$ Atualmente é Doutoranda em Políticas Públicas pela Universidade Estadual do Ceará. Mestra em Direito pela Universidade Federal do Ceará. e-mail: ebepgluz@gmail.com
} 


\section{Revista \\ Debates Insubmissos}

\section{INTRODUÇÃO}

O presente trabalho discute o fenômeno da liderança sob a perspectiva da teoria weberiana de dominação, dialogando com a vitória de Bolsonaro nas eleições de 2018. Liderança como relação de poder, no sentido weberiano de autoridade, em que o líder é reconhecido nessa qualidade por seus adeptos. Importante é informar que não se pretende compreender os atributos do líder, mas investigar como surge a figura do líder a partir dos ensinamentos de Max Weber e como este adquire legitimidade.

A questão central que norteia este artigo: i) A teoria weberiana consegue explicar a opção do eleitor brasileiro por Bolsonaro nas eleições de 2018 que o consagrou como Presidente da República?

Para responder a esta questão, propõe-se discutir os tipos de dominação teorizados por Weber, dando maior ênfase à Dominação Carismática. Entende-se que esta forma de poder de atração pode explicar, em parte e de forma superficial, a opção do eleitor brasileiro que elegeu Jair Messias Bolsonaro a Presidente da República nas eleições de novembro de 2018, tendo como consequência o rompimento da hegemonia do Partido dos Trabalhadores (PT) e do Partido da Social Democracia Brasileira (PSDB), nas eleições para Presidente da República, desde o pleito de 1994.

Deste modo, a metodologia utilizada nesta pesquisa assume caráter exploratóriodescritivo de natureza qualitativa, com abordagem teórica, fundamentada em dados secundários e publicações em jornais. A teoria de Max Weber orientou e fundamentou as ideias propostas neste estudo. O conceito de "governantes incidentais" elaborado por Abranches (2020) complementou a análise sobre as ações de Bolsonaro na qualidade de Presidente da República. O método da Análise de Conteúdo (BARDIN, 2011) foi utilizada para tratar os dados coletados.

Realizaram-se buscas no site da SciELO sobre publicações que remetessem ao tema. Os descritores utilizados nas buscas foram: Max Weber, Dominação Carismática, Bolsonaro, Eleições 2018. 
Este texto encontra-se dividido em seis partes com esta Introdução. Na primeira parte, discute os conceitos de política em Max Weber; em seguida, trabalha-se o conceito de dominação; após, o conceito de Dominação Carismática. A terceira parte apresenta a metodologia utilizada para elaboração deste artigo. Na penúltima parte, faz-se a análise para responder à questão central, abordando o tema Bolsonaro o "mito" que venceu as eleições de 2018 para presidência da República. Finaliza-se com as considerações finais, abordando alguns fatos e propondo novos estudos que possam dar seguimento ao tema.

\section{A POLÍTICA EM MAX WEBER}

A palavra política, na concepção de Max Weber (1970, p.55), tem amplo sentido e diversos significados. Embora o ponto de convergência esteja na tentativa de compreender como política, “apenas, a direção do agrupamento político. Hoje denominado 'Estado' ou a influência que se exerce em tal sentido".

A política é "o conjunto de esforços feitos visando a participação do poder ou a influenciar a decisão do poder, seja entre Estados, ou no interior de um único Estado" (WEBER, 1970, p.56).

O Estado traduz-se numa "relação de dominação sobre o homem pelo homem, fundada no instrumento da violência legítima", portanto, “o Estado só pode existir, sob condição de que os homens dominados se submetam à autoridade continuamente reivindicada pelos dominadores" (WEBER, 1970, p.57). Assim, quando um homem se dedica à política, seu desejo é possuir poder - "seja porque o considere como instrumento a serviço da consecução de outros fins, ideias ou egoístas, seja porque deseje o poder 'pelo poder', para gozar do sentimento de prestígio que ele confere." (idem, idem).

Uma vez que o Estado é uma relação de homens que dominam seus iguais, Weber acredita que, para isto, se faz necessário que os dominados se submetam a uma autoridade dos poderes dominantes cujo reconhecimento é partilhado coletivamente. Para tanto, apresenta três razões que fundamentam a legitimação da dominação: A primeira razão é o que denomina de 


\section{Revista \\ Debates Insubmissos}

Poder Tradicional, este exercido pelo patriarca ou senhor de terras. A segunda razão se manifesta pelo Poder Carismático, exercido pelo profeta ou pelo dirigente guerreiro eleito, identificado nos dons e atributos pessoais e extraordinários de um indivíduo. A terceira e última, a legitimação obtida pela via da legalidade, em razão da crença na validez de um estatuto legal de uma competência positiva, ou seja, a autoridade fundada na obediência, que reconhece obrigações conformes ao estatuto estabelecido. (WEBER, 1970, p. 57- 58). Esse é o poder do "servidor do Estado", atualmente.

Para o Estado Moderno, são estas as formas de dominação legítimas que interessam. Das três formas de legitimação do poder acima mencionadas, Weber se deteve no carisma: submissão ao carisma do chefe, pessoa em que os súditos depositam fé e esperança, o líder político. (1970, p.58). Assevera Weber que é no mundo ocidental que a figura livre do "demagogo" prolifera, sendo identificado facilmente, pois "se apresenta sob o aspecto do chefe de um partido parlamentar".

Weber identifica duas formas de fazer política: ou se vive "para" a política, ou se vive “da" política. Aquele que vive para a política, dá sentido à vida, a transforma, "por encontrar forma de gozo na simples posse do poder, ou porque o exercício dessa atividade lhe permite achar equilíbrio interno e exprimir valor pessoal, colocando-se a serviço de uma causa que dá significação a sua vida.” (1970, p.65). Já aquele que vive da política, tem nela sua fonte de renda.

É importante salientar que, para a sobrevivência dos partidos políticos, a existência de pessoas dispostas a "viverem da política" e a tenham como profissão principal tem seu significado. Em virtude disso, Weber assevera que essa dinâmica tem, como um dos seus resultados, a formação de uma larga categoria de dirigentes políticos criados a partir de características plutocráticas.

O autor conceitua o partido político moderno como uma "empresa de interesses", e argumenta que um dos princípios básicos dessa organização é a diferença entre uma camada de políticos ativos, militantes, escalados dentre o eleitorado; e estes que, por sua vez, compõem um corpo passivo que, oportunamente, participa. Essa distinção existente, entre poucos ativos 


\section{Revista \\ Debates Insubmissos}

e muitos passivos, é o princípio dos partidos que se organizam em suas disputas exatamente iguais às empresas, inclusive pela distribuição de cargos.

$\mathrm{Na}$ condição de "empresa de interesses", o partido reúne uma série de políticos profissionais. Dentre esses, Weber destaca o político carismático e os empresários políticos; porém não nos deteremos sobre os últimos. O líder carismático é aquele que, por seus dons pessoais e intransferíveis, coloca-se à frente da organização política, mobilizando e convencendo a maioria, fazendo seguidores. "Do ponto de vista psicológico, uma das mais importantes forças motoras com que possa contar o partido político reside na satisfação que o homem experimenta por trabalhar com a devoção de um crente em favor do êxito da causa de uma personalidade e não apenas em favor das abstratas mediocridades contidas num programa”. (1970, p.89).

Na opinião de Weber, o desenvolvimento da máquina partidária com esse perfil induz a um aprimoramento que tende a sobrepor a captação de votos e recursos às questões programáticas, criando verdadeiros partidos sem princípios, ou seja, uma organização de caçadores de recursos financeiros, empregos e poder.

Weber observa as características necessárias a um político carismático, afirmando haver "três qualidades determinantes do homem político: paixão, sentido de responsabilidade e senso de proporção" (WEBER,1970, p. 133). A paixão é o desejo consciente; a responsabilidade equivale ao sentimento de comprometimento; e o senso de proporção é associado ao momento certo de agir ou não em prol de um resultado sensato. Portanto Weber é categórico em afirmar que a "política se faz usando a cabeça e não as demais partes do corpo" (WEBER, 1970, p. 106).

Weber passa a definir dois tipos de ética: a ética das últimas finalidades e a ética de responsabilidade. Aquela, exemplificada através da ética proposta na religião cristã: “o cristão cumpre seu dever [segundo os mandamentos bíblicos], e, quanto aos resultados, confia em Deus" (WEBER, 1970, p.113). A ética de responsabilidade se orienta pela responsabilização: "sempre devemos responder pelas consequências previsíveis de nossos atos" (idem, idem, idem). Segundo Lage (2013, on line) o "importante aqui é distinguir que, enquanto a primeira 
visa às atitudes exemplares e coerentes com os fins últimos, a segunda mede os meios existentes para se chegar a tal fim, aceitando que mesmo completamente distante um pequeno avanço é razoável".

Dito isto, o autor defenderá que a política, tendo seu fundamento na dominação e no poder, conduz, invariavelmente a dilemas éticos.

Weber (2012, p. 187) constata que "todas as áreas da ação social, sem exceção, mostram-se profundamente influenciadas por complexos de dominação". Ela funciona, em determinados casos, como uma mola impulsionadora, seja dando forma a uma ação associativa, seja promovendo uma adequação funcional, isto é, orientando ações para um determinado objetivo (FERREIRA, 2001).

Para que ocorra a relação entre dominador e dominado, não apenas diretamente na esfera das relações ou dos mercados privados, mas também em outras situações de dominação, é necessário que a ordem seja obedecida. Nas palavras de Weber (2000, p. 140),

"Obediência" significa, para nós, que a ação de quem obedece ocorre substancialmente como se este tivesse feito do conteúdo da ordem e em nome dela a máxima de sua conduta e isso unicamente em virtude da relação formal de obediência, sem tomar em consideração a opinião própria sobre o valor ou desvalor da ordem como tal.

O cumprimento da ordem pode ocorrer por convicção de sua conformidade, por um sentimento de obrigação, por medo, por mero costume ou por vantagens pessoais. Quem exerce a dominação, ou o poder de mando, quem administra um poder de domínio é chamado de "dominador".

A subsistência de toda "dominação" depende da "autojustificação mediante o apelo aos princípios de sua legitimação" (WEBER, 2012, p. 197). O autor aponta três princípios: os que encontram sua validade nas regras estatuídas (pactuadas ou impostas); aqueles que encontram seu fundamento na tradição, por força do hábito; e por fim, os que tem validade no carisma, na graça concedida a determinada pessoa (WEBER, 2012, p. 198).

Destes princípios origina-se, o que Weber denomina de tipos puros de dominação legítima (WEBER, 2000, p. 141): 


\section{Revista \\ Debates Insubmissos}

1. de caráter racional: baseada na crença na legitimidade das ordens estatuídas e do direito de mando daqueles que, em virtude dessas ordens, estão nomeados para exercer a dominação (dominação legal), ou

2. de caráter tradicional: baseada na crença cotidiana na santidade das tradições vigentes desde sempre e na legitimidade daqueles que, em virtude dessas tradições, representam a autoridade (dominação tradicional), ou por fim,

3. de caráter carismático: baseada na veneração extra cotidiana da santidade, do poder heroico ou do caráter exemplar de uma pessoa e das ordens por esta reveladas ou criadas (dominação carismática).

Assim, sendo as ordens baseadas em leis, normas, estatutos, regimentos, a obediência decorre de uma ordem impessoal, objetiva e legal. Neste caso, o poder de mando é dado aos superiores em decorrência dessas normas.

$\mathrm{Na}$ dominação tradicional a obediência tem um caráter pessoal, "obedece-se à pessoa do senhor nomeada pela tradição e vincula a esta (dentro do âmbito de vigência dela), em virtude de devoção aos hábitos costumeiros" (WEBER, 2000, p. 141).

Por último, a dominação carismática é decorrente da "obediência ao líder carismaticamente qualificado como tal, em virtude de confiança pessoal em revelação, heroísmo ou exemplaridade dentro do âmbito da crença nesse seu carisma" (WEBER, 2000, p. 141). Nesse sentido, a personalidade do líder é um elemento do seu caráter, que por si só não explica a relação do líder com seus adeptos, ou seja, "suas qualidades pessoais não existem fora dessa relação, pois é o modo como elas são avaliadas subjetivamente pelos adeptos que as constituem: trata-se de propriedades atribuídas" (SELL, 2018, p. 5).

\section{DOMINAÇÃO CARISMÁTICA}

O patriarcalismo tem como qualidade importante a continuidade através da estrutura familiar de modo que o direito de sucessão privado se torna meio de legitimação da autoridade pública, onde o patriarca é o líder natural da vida cotidiana. A estrutura burocrática, embora possua caráter cotidiano, tem dentro da esfera racional uma formação permanente em respeito a seu sistema de regras racionais (WEBER, 2000). No que concerne à dominação carismática, esta não conhece nenhuma forma e nenhum procedimento ordenado de nomeação ou demissão, nem de carreira ou promoção, não conhece nenhum salário, nenhuma instrução especializada 


\section{Revista \\ Debates Insubmissos}

ou regulamentada do portador do carisma ou de seus assistentes, assim como nenhuma instância controladora à qual se possa apelar. Nesse sentido Weber afirma:

A dominação carismática, como algo extra cotidiano, opõe-se estritamente tanto à dominação racional, especialmente a burocrática, quanto à tradicional, especialmente a patriarcal e patrimonial ou a estamental. Ambas são formas de dominação especificamente cotidianas - a carismática (genuína) é especificamente o contrário. (WEBER, 2000, p.160).

A estrutura carismática é passional, desconhece regras, conhece apenas determinações e limites imanentes das afeições. "O portador do carisma assume tarefas que considera adequadas e exige obediência e adesão em virtude de sua missão" (WEBER, 2012, p.324). Se as encontra, ou não, depende do êxito. Se aqueles aos quais ele se sente enviado não reconhecem sua missão, sua exigência fracassa. Se o reconhecem, é o senhor deles enquanto sabe manter seu reconhecimento mediante provas. O reconhecimento do líder carismático é dever daqueles aos quais se dirige sua missão.

O carisma é, em regra, na abordagem de Weber:

[...] qualitativamente singular, e por isso determina-se por fatores internos e não por ordens externas o limite qualitativo da missão e do poder de seu portador. Segundo seu sentido e conteúdo, a missão pode dirigir-se, e em regra o faz, a um grupo de pessoas determinado por fatores locais, étnicos, sociais, políticos, profissionais ou de outro tipo qualquer: neste caso, encontra seus limites no círculo destas pessoas (WEBER, 2012, p. 324).

Weber prossegue explicando a origem da legitimidade do herói carismático:

A existência da autoridade carismática, de acordo com a sua natureza é especificamente lábil. [...] O herói carismático não deriva sua autoridade de ordens e estatutos, como o faz a "competência" burocrática, nem de costumes tradicionais ou promessas de 30 fidelidade feudais como o poder patrimonial, mas sim consegue e a conserva apenas por provas de seus poderes na vida. Deve fazer milagres se pretende ser um profeta, e realizar atos heroicos, se pretende ser um líder guerreiro. Mas, sobretudo deve "provar" sua missão divina no bem-estar daqueles que a ele devotamente se entregam. (WEBER, 2012, p. 326).

A dominação carismática pura não conhece normas jurídicas, leis e a jurisdição formal. Seu direito concentra-se no resultado concreto da relação pessoal de graça celestial e força heroica. Comporta-se de maneira revolucionária, invertendo todos os valores e rompendo soberanamente com todas as normas tradicionais ou racionais, sendo este, "o meio mais frequente de subverter ou abolir um regime tradicional ou legal” (FREUND, 2003, p. 176). 


\section{Debates Insubmissos}

Revista

Em consonância com o apresentado, Weber afirma que:

O poder do carisma, [...] fundamenta-se na fé em revelações e heróis, na convicção emocional da importância e do valor de uma manifestação de natureza religiosa, ética, artística, científica, política ou de outra qualquer, no heroísmo da ascese, da guerra da sabedoria judicial, do dom mágico ou de outro tipo. Esta fé revoluciona os homens "de dentro para fora" e procura transformar as coisas e as ordens segundo seu querer revolucionário. (WEBER, 2012, p.327).

O carisma, em suas formas de manifestação supremas, rompe todas as regras e tradições; em vez da piedade diante dos costumes antiquíssimos e por mais sagrados, exige o carisma sujeição íntima ao nunca visto, absolutamente singular. Neste sentido, torna-se, o carisma, o maior poder revolucionário da história. Situações exteriores podem motivar esses processos de mudanças, dentre as causas, política, econômica “ou então por uma transformação dos espíritos (na ordem religiosa ou intelectual)”. (FREUND, 2003, p. 176).

Deste modo, o portador do carisma desfruta da autoridade em virtude de uma missão supostamente encarnada em sua pessoa, missão que tem sido, em suas manifestações supremas, de caráter revolucionário, invertendo todas as escalas de valores e derrubando os costumes, as leis e a tradição.

Weber afirma que à medida em que a relação entre dominador e dominados assume um caráter permanente, "a dominação carismática [...] tem de modificar substancialmente seu caráter" (WEBER, 2000, p.161-162), seja tradicionalizando-se ou racionalizando-se, ou ambas as coisas. A este fenômeno o autor reconhece como "rotinização do carisma" (idem, id).

A rotinização que transforma o carisma em tradição, e consequentemente em ordem cotidiana estabelecida, é vista por Weber como sendo fundamentalmente o motor da história.

[...] o carisma, em suas formas de manifestação supremas, rompe todas as regras de toda a tradição e mesmo inverte todos os conceitos de santidade. Em vez da piedade diante dos costumes antiquíssimos e por isso sagrados, exige o carisma a sujeição íntima ao nunca visto, absolutamente singular, e, portanto, divino. Neste sentido puramente empírico e não-valorativo, é o carisma, de fato, o poder revolucionário especificamente criador da história. (WEBER, 2012, p. 328)

Ressalta-se que, para Weber, apesar de o carisma partir da transformação interna da comunidade "de dentro para fora”, a dominação carismática só é possível a partir de 
[...] situações extraordinárias externas especialmente políticas ou econômicas, ou internas psíquicas particularmente religiosas ou de ambas em conjunto. Nasce da excitação comum a um grupo de pessoas, provocada pelo extraordinário, e da entrega ao heroísmo, seja qual for o seu conteúdo. (WEBER, 2012, p. 331).

A partir desses conceitos, buscam-se encontrar possíveis respostas para a vitória de Jair Bolsonaro em 2018, que tem como consequência o rompimento da tradição dicotômica da disputa presidencial entre dois partidos, desde o ano de 1994, quando Fernando Henrique Cardoso, representante do PSDB, e Luiz Inácio Lula da Silva, representante do PT concorreram ao pleito. Desse pleito, saiu vitorioso no primeiro turno o candidato do PSDB. Nas eleições seguintes antes de 2018, ambos os partidos disputaram a preferência dos eleitores para ocupar o cargo eletivo de Presidente da República, com reais possibilidades de vitórias.

\section{O SURGIMENTO DO “MITO” NAS ELEIÇÕES DE 2018 PARA PRESIDENTE DA REPÚBLICA}

Matéria publicada no Jornal do Brasil com o título "O confronto como estilo", de Bastos e Ferreira (2020, on line) faz a seguinte colocação,

Max Weber (1864/1920), o clássico pensador alemão, dificilmente reconheceria Bolsonaro como um político ancorado na dominação legítima, representante do poder de líderes carismáticos, muito embora quase sempre em efetivo confronto com a legalidade, a dominação racional-burocrática.

A campanha eleitoral de 2018 ocorreu em um contexto marcado por sentimentos anticorrupção, com a contribuição e o protagonismo das redes sociais, notadamente do Whatsapp bem como do Twitter, adicionando a isso a proliferação de Fake News. O tempo de televisão, instrumento tido, até então, como ferramenta fundamental para a apresentação de propostas e a consolidação dos votos, se mostrou não ser $\Theta$ suficiente de forma individual, para alavancar uma candidatura. Muito embora não tenha participado dos debates promovidos por emissoras de TV, nem apresentado um plano de governo claro, Jair Messias Bolsonaro passou a se apresentar nas pesquisas de opinião como o candidato favorito.

Outros fatores como a crise econômica brasileira, o aumento da taxa de desemprego, aliados às notícias de escândalos de corrupção que eram objeto de investigação pela Operação Lava Jato, com a atuação do Poder Judiciário e do Ministério Público (MP) com ampla 


\section{Revista \\ Debates Insubmissos}

divulgação da grande mídia formadora de opinião, influenciaram o eleitor em sua escolha. Citam-se como exemplos, no pleito de 2018, os seguintes fatos: contra Alckmin ${ }^{4}$, o MP de São Paulo impetrou com ação de improbidade administrativa, alegando a existência de caixa dois. Recorrências de ações dessa natureza, em períodos de campanha eleitoral, enfraqueceram o discurso do PSDB e que então se fundamentava na pauta de renovação e posição anticorrupção. No que se refere ao PT, esse também não passou ileso pelas ações do MP de São Paulo, que representou contra Haddad, candidato pelo $\mathrm{PT}^{5}$, por improbidade administrativa alegando suposto enriquecimento ilícito.

Entretanto, o que mais chamou a atenção da população brasileira foi o fato de Bolsonaro, ainda como candidato, ter sido "esfaqueado" em plena campanha, tendo esse incidente o colocado sob os holofotes da mídia, e muito embora não tenha participado dos debates nem ter apresentado um plano de governo consistente, tal fato exerceu uma influência demasiada sobre o eleitor. Portanto, esse conjunto de fatores, dentre outros mais, foi determinante para a mudança drástica no cenário político brasileiro. Há 24 anos, desde 1994, o Brasil observava uma alternância pendular no poder dividida entre dois partidos, o PT e o PSDB. Apenas candidatos desses dois partidos demonstravam ter reais chances de vencer uma eleição presidencial. A disputa em segundo turno sempre acabava ocorrendo entre petistas e tucanos, forçando coligações com outros partidos, inclusive com ideologias diversas, o que os obrigava a estabelecerem, quando eleitos, governos de coalisão.

Esses fatos contribuíram para gerar um clima de polarização no país, onde a direita, representada pelo PSL de Jair Bolsonaro contra a esquerda, reunida em torno do PT que tinha como candidato Fernando Haddad, representando assim a suposta possibilidade de mudança

\footnotetext{
${ }^{4}$ Jornal Nacional - G1 - MP de São Paulo entra com ação de improbidade contra Alckmin (PSDB) Ministério Público acusa o ex-governador de São Paulo de ter recebido R \$ 7,8 milhões da Odebrecht na campanha de reeleição, em 2014. Disponível em: https://g1.globo.com/jornal-nacional/noticia/2018/09/05/mp-de-sao-pauloentra-com-acao-de-improbidade-contra-alckmin-psdb.ghtml

${ }^{5}$ Correio Braziliense. Haddad responde a oito ações após gestão em SP. Desde que a primeira ação contra o petista foi movida pelo MP de São Paulo, em 2015, o ex-prefeito acumula algumas vitórias e derrotas parciais, sem condenação até $\quad$ o momento. Disponível em: https://www.correiobraziliense.com.br/app/noticia/politica/2018/09/26/interna_politica,708364/haddadresponde-a-oito-acoes-apos-gestao-em-sp.shtml
} 
(Bolsonaro) e a continuidade da corrupção (Haddad), esses temas permearam os debates e exerceram influência no eleitorado. Essa polarização, ocorreu num clima tão ferrenho, que candidatos com boas propostas e planos, experiência e representatividade ficaram alijados dessa disputa que potencialmente poderia ter tido outro desfecho.

O resultado do primeiro turno aparece o PSL com Jair Messias Bolsonaro, que desbanca o PSDB, passa ao segundo turno das eleições majoritárias à Presidência da República, para concorrer com o PT.

Jair Bolsonaro, pautado em uma agenda neoliberal derivada do Instituto Millenium ${ }^{6}$ ao qual é ligado o economista Paulo Guedes, que viria a ser seu ministro da Economia, propôs políticas de combate a corrupção, a diminuição da maioridade penal para 16 anos, flexibilização da política do desarmamento, privatizações, dentre outras. Passou a ser chamado de "mito", de incorruptível, por seus apoiadores pelo discurso eminentemente conservador e pelo fato de "ter sido o único deputado federal do PP, partido a que era filiado à época, a não votar com o governo em projetos nos quais se demonstrou, no processo do mensalão, ter havido compra de votos." (SANTOS, 2020, on line).

Venceu as eleições de 2018 no segundo turno, com expressiva maioria, deixando batido o PT. Sobre esse cenário, Weber ensina que,

A criação de uma dominação carismática, no sentido "puro" [...] é sempre resultado de situações extraordinárias externas, especialmente políticas ou econômicas [...]. Nasce da excitação comum a um grupo de pessoas, provocada pelo extraordinário, e da entrega ao heroísmo, seja qual for o seu conteúdo. (WEBER, 2012, p. 331).

Jair Bolsonaro surge em um contexto de profundo descrédito dos eleitores nos políticos, e por vezes com grande razão. Em seu pronunciamento por ocasião de sua posse, adota um discurso populista conclama a todos para ajudá-lo a "salvar a pátria",

Aproveito este momento solene e convoco cada um dos congressistas para me ajudarem na missão de restaurar e de reerguer nossa pátria, libertando-a, definitivamente, do jugo da corrupção, da criminalidade, da irresponsabilidade econômica e da submissão ideológica. Temos, diante de nós, uma oportunidade única de reconstruir o nosso país e de resgatar a esperança dos nossos compatriotas. Estou

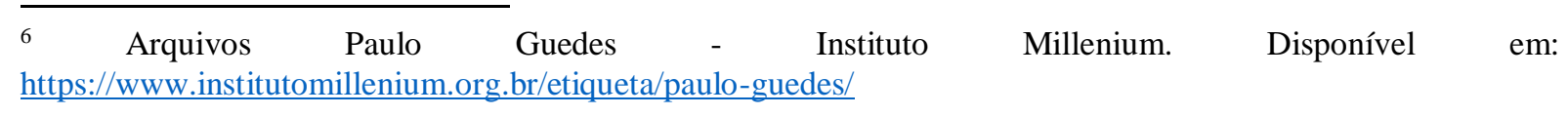




\section{Revista \\ Debates Insubmissos}

certo de que enfrentaremos enormes desafios, mas, se tivermos a sabedoria de ouvir a voz do povo, alcançaremos êxito em nossos objetivos, e, pelo exemplo e pelo trabalho, levaremos as futuras gerações a nos seguir nesta tarefa gloriosa. (BOLSONARO apud GUIRADO, 2019, p. 4).

Abranches chama Bolsonaro do tipo de "governantes incidentais", isto porque esses

Saem da periferia ou de fora da política para o centro de poder. Conquistam o governo em função de um conjunto imprevisto e irreprodutível de fatores. [...]. Eles surgem das reações de um eleitor perdido, volúvel, assustado e descontente com as mudanças estruturais que se manifestam como crises. [...] (ABRANCHES, 2020, s/n).

Weber afirma que depois da explosão de apoio, alimentado por um discurso de um mundo melhor, surge, normalmente, a rotinização do carisma.

A rotinização significa a volta do dia a dia, exige-se a obediência a lógica da racionalidade das ações e práticas regulares imputada aos homens públicos que exercem funções políticas. Essas são resguardadas por códigos e costumes comuns a sociedade. O poder pessoal de Bolsonaro, baseado no carisma se transforma em poder legal, após vencer as eleições. Sua gestão, que se iniciou em janeiro de 2019, deve ser pautada pelos princípios constitucionais, em conformidade com as regras e normas vigentes do sistema jurídico brasileiro.

Entretanto, a esse processo de transformação, Bolsonaro impõe resistência. Falta-lhe enquadramento de suas ações na ordem racional-legal e obrigatória que o cargo de Presidente da República exige. Desde seu primeiro ano de mandato até momento, num cenário caótico, vêm-se os resultados da falta de um plano de governo, para as diversas áreas de atuação, especialmente diante da pandemia COVID-19, cujos dados, em 06 de abril de 2021, registravam quase 340 mil óbitos informações do Ministério da Saúde (BRASIL, 2021).

Avritzer (2020, p. 10) afirma que Bolsonaro chegou à Presidência "não como líder político, mas como alguém disposto a destruir políticas e políticos”. Seu discurso permanece o mesmo - contra os inimigos da pátria, contra as impurezas da política e cultura (BARBOSA, 2020), contra a ciência ou qualquer instituição que critique a si e/ou seus familiares. Cioccari et al. (2018, p. 206) entendem que "Bolsonaro utiliza o discurso do medo para respaldar-se num país em que há a construção de um imaginário no qual o delinquente é sempre um "outro" distante do "cidadão de bem" e que obstrui o bom andamento da sociedade". 


\section{Revista \\ Debates Insubmissos}

Sua fala é negacionista da ciência, é contraditória, insegura e sem fundamento; na sua prática confirma a ascensão a passos largos da corrupção, do privilégio, da proliferação da mentira, da desqualificação do intelecto, do desprezo pelas minorias; e sua política econômica e social é catastrófica, condenando milhares de pessoas à miséria e à morte (CIOCCARI et al., 2018).

Nesse viés, fez um pronunciamento no Palácio do Planalto em 07 de outubro de 2020 afirmando que: "É um orgulho, é uma satisfação que eu tenho, dizer a essa imprensa maravilhosa que eu não quero acabar com a Lava Jato. Eu acabei com a Lava Jato, porque não tem mais corrupção no governo. Eu sei que isso não é virtude, é obrigação" (GALLAS, 2020, on line).

Dirige-se aos adversários com desdém, usando vocabulário limitado e chulo, para a impressa, à qual critica e ataca árdua e frequentemente, profere palavras de baixo calão, impróprias de serem repetidas, além de, não raro, se autoelogiar de modo a fazer inveja a Narciso. Utiliza de falsa modéstia, produz um discurso falacioso e retórico que revela não ser, de fato, um mito, mas uma espécie de engodo, criado para atrair e enganar os eleitores brasileiros mais desatentos em 2018 ,

[...] não por ser de direita, nem por sua inépcia pessoal e política, mas por sua mentalidade autoritária e intolerante. Ele tem conseguido desgastar as instituições democráticas [...] Nunca esteve na sua agenda construir uma nova base organizacional para a governança, e por isso tanta dificuldade para formular políticas coerentes e relevantes" (ABRANCHES, 2020, s/n).

O Estado Democrático de Direito, baseia-se na dominação legal-racional, a legalidade e a legitimidade são requisitos estabelecidos na Constituição de 1988. A burocracia brasileira é estruturada, com competências, limites e funções exclusivas e definidas na Carta Magna de 1988, inclusive para o detentor do cargo de Chefe de Governo e Chefe de Estado.

O fim da Operação Lava Jato, em regra, não deve ser atribuição do Presidente da República, tendo em vista a separação dos poderes. O Ministério Público é o detentor da competência para tal feito. Entretanto, esse é apenas um exemplo de ato em que o Presidente Bolsonaro toma atribuições para si, em uma clara demonstração de usurpação (ou tentativa) de 
competência. Ele se põe acima de todos. Guinado fez estudos sobre o discurso de posse de Bolsonaro e constatou:

Se o Discurso de Posse configurou um sujeito de plenos poderes, ungido por milagre de Deus, garantido pelas eleições, identificado com a Pátria, e que se predestina a defendê-la de todos os ataques de ideias, instituições ou organizações "contrárias" [...] Deus e seu Mito, fundidos no sujeito configurado nesse discurso, que se faz assim, mais que inaugural. Veio para marcar a ferro e fogo seus sinais. (GUINADO, 2019, p. 6-7).

Age como se estivesse acima do Estado de direito. De acordo com seus caprichos, utiliza a máquina pública em proveito próprio e de seus próximos. Particularmente, em relação às possibilidades de investigações sobre corrupção, expede Decretos que dão suporte e aparelha as instituições com o objetivo de dificultar identificação no rastreamento de armas, utilizadas em crimes praticados tanto pelo homem comum, como pela polícia, quando de suas operações, dentre outros incontáveis exemplos, que não cabem aqui serem listados. Bolsonaro, com suas práticas, tenta ludibriar o povo brasileiro, ao tempo em que

Sua família (esposa, filhos) e assessores diretos, têm inúmeros processos transitando em diversos tribunais: o caso dos laranjas do PSL; os depósitos em contas do filho e da esposa, por um ex-assessor, o famoso Queiróz; evidências de laços com implicados no assassinato da vereadora Marielle Franco e de seu motorista Anderson Gomes; a descoberta de $39 \mathrm{~kg}$ de cocaína carregados em avião presidencial na Espanha; os 115 fuzis AR-15 encontrados na casa do vizinho de Bolsonaro, e amigo da família; o uso de recursos do fundo partidário para pagar a viagem de lua de mel de Eduardo Bolsonaro com a coach e psicóloga Heloísa Wolf; a investigação, pelo MP-RJ, de Carlos Bolsonaro, por denúncias de nepotismo - ele nomeou ao menos sete parentes como funcionários fantasmas em seu gabinete. (PINTO, 2020, on line)

É provável que o fim da Operação Lava Jato, conforme apregoado, tenha sofrido interferência do Presidente, não pelo seu autoelogio, em que diz não existir corrupção no seu governo, mas exatamente porque existe corrupção em seu governo.

É pertinente, aqui, ressaltar, que Augusto Aras ${ }^{7}$, nomeado por Bolsonaro em 2019 para Procurador Geral da República, determinou que a força-tarefa curitibana só teria mandato para funcionar até o dia 31 de janeiro de 2021, ou seja, não era ainda o fim imediato, mas o enfraquecimento da operação. É importante esclarecer que não se defende, aqui, a Operação

\footnotetext{
${ }^{7}$ Bolsonaro quebrou uma regra não oficial, ao escolher um PGR que não havia sido escolhido em votação dos membros do MPF, organizada pela Associação Nacional dos Procuradores da República (ANPR). Aras foi o primeiro escolhido fora da lista, desde 2003.
} 


\section{Revista \\ Debates Insubmissos}

Lava-Jato, até porque entende-se que ela teve papel de relevância na atuação contra a corrupção, entretanto em determinado momento foi utilizada erroneamente para exercer interferência político-ideológica durante seu andamento, inclusive contribuindo sobremaneira para o impedimento de participação do candidato do PT nas eleições de 2018, então considerado favorito nas pesquisas eleitorais.

\section{CONSIDERAÇÕES FINAIS}

Neste texto, procurou-se compreender o que representou Jair Bolsonaro no cenário político das eleições de 2018, a partir da categoria de dominação carismática proposta por Weber, e seu enquadramento legal ao cargo de Presidente da República.

Entende-se que a autoridade carismática se legitima no fato de aparecer aos olhos dos dominados como um poder exercido em benefício à sua proteção. A legitimidade do detentor do carisma não está ancorada nas regras e nas instituições, mas na figura detentora de poder carismático, aquele a que se atribui a denominação de "herói e salvador", que surge em oposição às forças malévolas e dissimuladas (violência, corrupção).

Em um primeiro momento, poder-se-ia pensar que, de fato, Bolsonaro era o "mito" em forma de político, mas o seu processo de rotinização revela que ele é o que sempre foi ao longo de 28 anos no exercício do cargo de Deputado Federal, isto é, um político de carreira, despreparado, inexpressivo e refratário às regras que pautam o atual cargo ocupado que ele está ocupando. Inclusive, mostrando-se insensível ao lastro de mortes ocasionado pela Covid-19 no Brasil, que já vitimou fatalmente o número expressivo de quase 340 mil pessoas.

Por fim, este é um momento de vulnerabilidade da população, a mesma que "elegeu um presidente sabidamente desequilibrado" (AVITZEZ, 2020, p. 56), e que agora sofre as consequências desse governo destituído de empatia para as várias questões sob a sua responsabilidade, que afetam todas as áreas, com destaque para os aspectos políticos, econômicos, ambientais, diplomáticos, sociais e de saúde, na qual tem maior relevância a grave crise sanitária. Em suma uma completa demonstração da incapacidade para encontrar caminhos 
para enfrentar ou, ao menos, minimizar os problemas, de modo a aglutinar o sistema político e oferecer as respostas necessárias para superar esse conjunto de crises.

\section{REFERÊNCIAS}

ABRANCHES, Sérgio. A era do imprevisto: A grande transição do século XXI. São Paulo: Companhia das Letras. 2020. ebook.

AVRITZER, Leonardo. Política e antipolítica: A crise do governo Bolsonaro. São Paulo: Todavia. 2020.

BARDIN, L. Análise de conteúdo. São Paulo: Edições 70, 2011.

BASTOS, A. W.; FERREIRA, L. P. O confronto como estilo. In: Jornal do Brasil. 2020. Disponível em: https://www.jb.com.br/pais/artigo/2020/04/1023284-o-confronto-comoestilo.html. Acesso em: 20 fev. 2021.

BRASIL. Ministério da Saúde. Painel Coronavírus. Disponível em: https://covid.saude.gov.br/. Acesso em: 06 abr. 2021.

CIOCCARI et al. Armas, ódio, medo e espetáculo em Jair Bolsonaro. Revista Alterjor, vol. 18, no 2, julho de 2018, p. 201-14. Disponível em: https://www.revistas.usp.br/alterjor/article/view/144688 Acesso em: 20mar. 2021.

FERREIRA; Hamilton Almeida. Liderança Carismática e Populismo: Um estudo sobre a dominação e a transição do poder político em Montes Claros na década de 80. Dissertação apresentada à Universidade Federal de Santa Catarina - UFSC para obtenção do título de Mestre em Direito. Disponível em:

https://repositorio.ufsc.br/bitstream/handle/123456789/79403/182017.pdf?sequence=1. Acesso 09 out. 2020.

FREUND, Julien. Sociologia de Max Weber. Rio de Janeiro: Forense Universitária. 5.a edição. 2003.

GALLAS, Daniel. 'Acabar com Lava Jato' tem impacto quase zero na popularidade de Bolsonaro, diz pesquisador. Disponível em: https://www.bbc.com/portuguese/brasil54468361. Acesso em: 11 out. 2020.

GUIRADO, Marlene. Entre Discurso e Ato, há muito mais do que se imagina. Universidade de São Paulo, Instituto de Psicologia. São Paulo, SP, Brasil. 2019. Disponível em: https://www.scielo.br/pdf/pusp/v30/1678-5177-pusp-30-e190027.pdf 
LAGE, Daniel. Reflexões sobre a leitura de "A Política como Vocação" de Max Weber. 2013. Disponível em: https://lage.milharal.org/2013/05/24/reflexoes-sobre-a-leitura-de-apolitica-como-vocacao-de-max-weber/. Acesso em: 11 jan. 2021.

PINTO, Lúcio Flávio. O “carisma” de Bolsonaro. Disponível em: https://lucioflaviopinto.wordpress.com/2020/02/23/o-carisma-de-bolsonaro/. Acesso em: 11 out. 2020.

SANTOS; Marcos Ricardo dos. "Jair Bolsonaro: algumas razões para explicar o fenômeno do "mito'". Disponível em: https://www.gazetadopovo.com.br/vida-publica/jairbolsonaro-algumas-razoes-para-explicar-o-fenomeno-do-mitodt0wz8s8agwlmwpz02yia8fnq/. Acesso em: 11 jan. 2021.

SELL, c. e. Poder Instituído e Potência Subversiva: Max Weber e a dupla face da dominação carismática. Rev. bras. Ci. Soc. [online]. 2018, vol.33, n.98, e339814. Epub July 26. 2018. Disponível em: https://www.scielo.br/scielo.php?pid=S010269092018000300509\&script=sci_abstract\&tlng=pt Acesso em: 21 fev. 2021.

WEBER, Max. Economia e Sociedade: fundamentos da sociologia compreensiva. Volume 2. Tradução de Regis Barbosa e Karen Barbosa; rev. Téc. Gabriel Cohn, $4^{a}$ ed. Brasília: Editora Universidade de Brasília. 2012.

WEBER, Max. Economia e Sociedade: fundamentos da sociologia compreensiva. Volume 1. Tradução de Regis Barbosa e Karen Elsabe Barbosa. rev. Téc. Gabriel Cohn, $3^{\text {a }}$ ed. Brasília: Editora Universidade de Brasília. 2000.

WEBER, Max. Ciência e Política duas vocações. Edição: $18^{a}$ edição. São Paulo: Editora: CULTRIX .1970.

Submetido em: 23/01/2021

Aprovado em: 19/07/2021 